\title{
Challenges of Contract Farming among Small-Scale Commercial Vegetable Farmers in Eastern Cape South Africa
}

https://dx.doi.org/10.4314/jae.v22i3.19

\section{Khapayi Musa *}

Department of Agriculture and Game Management, Nelson Mandela University, Port Elizabeth, South Africa. E-mail: musa.khapayi@mandela.ac.za*; +2741504 3632.

\section{Niekerk Pieter Van}

Department of Agriculture and Game Management, Nelson Mandela University, Port

Elizabeth, South Africa. E-mail:Pieter.vniekerk@mandela.ac.za

\section{Celliers Phillip Retief}

Department of Agriculture and Game Management, Nelson Mandela University, Port Elizabeth, South Africa. E-mail: Phillip.Celliers2@mandela.ac.za

${ }^{*}$ Corresponding author

\begin{abstract}
This research investigated the effectiveness of contract farming in commercialisation of small-scale vegetable farmers. The broad objectives of the study were to investigate the agri-business challenges inherent in contract farming and the government incentives required by agribusiness firms to engage small-scale vegetable farmers in contract farming programmes. A sample of 47 small-scale farmers and 15 agribusiness firms involved in contract farming production of vegetables were selected in Sarah Baartman district municipality in the Eastern Cape province of South Africa. Focus group discussions and in-depth interviews were chosen as data collection tools to identify the agribusiness challenges inherent in contract farming relationships between the parties. Findings from the study revealed that the contract farming environment in the area surveyed was highly polarised and characterised by a fundamental conflict of interest between agribusiness and farmers. Among the divergent key factors inhibiting contract farming engagement were a lack in terms of quality seeds, trust, entrepreneurial skills and formal contract agreements. The study recommends a collaborative partnership between private firms and government, with state support through revised policies and development programmes. These amendments are crucial to enhancing the engagement of small-scale vegetable farmers in lucrative agri-food chains.
\end{abstract}

Keywords: agribusiness, commercialisation, contract farming, small-scale farmers.

\section{Introduction}

The majority of the world's poor directly and indirectly depend on agricultural production for survival (Fischer \& Qaim, 2012). Most are small-scale farmers often living in remote areas with poor infrastructure, facing many constraints that impede them from taking advantage of market opportunities (Ha, Bosch \& Nguyen, 2015). Securing market access for agricultural produce of small-scale farmers has been globally identified as one of the most crucial strategies towards rural development and 
Creative commons User License: CC BY-NC-ND

Abstracted by: EBSCOhost, Electronic Journals Service (EJS), Google Scholar, Journal Seek, Scientific Commons,

Food and Agricultural Organization (FAO), CABI and Scopus
Journal of Agricultural Extension

Vol. 22 (3) October, 2018

ISSN(e): 24086851; ISSN(Print); 1119944X

http://journal.aesonnigeria.org

http://www.aiol.info/index.phpliae

Email: editorinchief@aesonnigeria.org

poverty alleviation ( $\mathrm{Ha}$ et al., 2015). South Africa shares common characteristics with many other developing countries in the world (Department of Agriculture, Forestry and Fisheries, 2010). About 16 million South Africans are living in poverty, with numbers highest in the rural areas and most small-scale farmers directly and indirectly being dependent on agriculture for survival (Department of Agriculture, Forestry and Fisheries, 2010). Linking small-scale farmers with lucrative agricultural markets through fresh food retail chains is seen as one of the emerging agricultural practices to develop the subsistence farming sector as a main economic sector and to revitalise the rural economy and alleviate poverty levels in the developing rural areas of South Africa (Koranteng, 2010; Ha et al., 2015).

The topic of linking small-scale farmers into high-value markets in South Africa has been receiving attention particularly from the government and academic institutions alike (Jordaan, 2012; Ha et al., 2015). The South African government has pledged itself to improving agricultural production, emphasising the subsistence farming sector Research conducted on linking small-scale farmers into the mainstream agricultural economy in South Africa includes, amongst others, the studies by renowned academics and global institutions such as Little and Watts (1994); Johanson and Saint (2007); Randela, Alemu, Groenewald (2010); Baloyi (2010); Koranteng (2010); Ayinke (2011); Jordaan (2012); Minot (2012); Oya (2012); Greenberg and Paradza (2013); Sikwela and Mushunje (2013) and Ha et al. (2015). Despite the efforts and the substantial investments made and the various policies and initiatives instigated to fast-track the linkages of small-scale farmers into high-value markets, the success stories of previously disadvantaged farmers successfully operating in commercial agri-food chains are rare (Ortmann \& King, 2010; Jordaan, 2012; Mmbengwa, Groenewald, Van Schalkwyk \& Maiwashe, 2012).

According to extensive research by Ndanga and Kirsten (2008), Baloyi (2010), Jordaan (2012), Louw, Jordaan, and Mmbengwa et al. (2012), the agribusiness challenges inherent in contract farming and the factors and mechanisms influencing the use of contract farming agreements in the transition to commercial farming by small-scale farmers have not been thoroughly explored. This study therefore endeavours to investigate the agribusiness challenges inherent in contract farming and the conditions and incentives required by agribusiness firms to engage smallscale vegetable farmers in contract farming programmes.

The commercialisation of small-scale farmers' production and enhancing their integration into lucrative markets and more inclusive value chains remain a challenge for the majority of governments in sub-Saharan Africa (Johanson and Saint, 2007; Ayinke, 2011). Linking small-scale farmers into agribusiness value chains is one of the rural development strategies being promoted in South Africa to address the challenges faced by small-scale farmers in terms of integration into markets. Researchers advocate the promotion of contract farming as a promising mechanism with the potential to improve technical efficiency in production as well as providing assured lucrative markets for small-scale farmers (Louw, Vermeulen, Kirsten \& Madevu, 2007; Baloyi, 2010; Koranteng, 2010; Ayinke, 2011). Minot (2011) and Johanson and Saint (2007) argue that contract farming appears to be the future of 
Creative commons User License: CC BY-NC-ND

Abstracted by: EBSCOhost, Electronic Journals Service (EJS), Google Scholar, Journal Seek, Scientific Commons,

Food and Agricultural Organization (FAO), CABI and Scopus
Journal of Agricultural Extension

Vol. 22 (3) October, 2018

ISSN(e): 24086851; ISSN(Print); 1119944X

http://journal.aesonnigeria.org

http://www.aiol.info/index.phpliae

Email: editorinchief@aesonnigeria.org

agricultural production, access to markets and the reduction of poverty in rural communities particularly in this age of biotechnology. However, the challenges inherent in contract farming to both agribusiness firms and small-scale farmers, as well as the conditions enhancing the inclusion of small-scale farmers into modern value chains, remain open to debate (Ortmann \& King, 2010; Jordaan, 2012; Mmbengwa, Groenewald, Van Schalkwyk \& Maiwashe, 2012).

According to Berdegué, Biénabe and Peppelenbos (2008) a key pattern in successful contract farming is the collaborative arrangement between a trained and organised small-scale farmer, a receptive ${ }^{1}$ agribusiness firm and lastly conducive public policies and programmes. Such arrangements can benefit from specialised partnership facilitation. Van Schalkwyk, Groenewald, Fraser, Obi and Van Tilburg (2012) argue that agribusiness firms in South Africa operate on commercially sustainable premises. These companies are well-positioned and have the experience and knowledge necessary to provide the proper support services crucial to the development of smallscale farmers. The authors contend that agribusiness firms not only compete domestically but also on the global market. Therefore, these firms are in a unique position to assist small-scale farmers to become commercially successful. They can provide assured market access where small-scale producers could sell their produce, provide adequate funding for working and fixed capital and access to support in terms of agricultural practices (Van Schalkwyk et al., 2009; Coetzee, 2012).

Notwithstanding the role that agribusinesses can play in linking small-scale farmers into lucrative agricultural markets, engaging with small-scale farmers comes at a cost to agribusiness firms (Louw et al., 2007; Baloyi, 2010). Hence many agribusiness firms tend to procure their commodity or raw materials from more established largescale farmers who in most instances also export their produce (Louw et al., 2007; Baloyi, 2010). This is done to ensure that the product procured meets the local as well as the international standards and maintain low transaction costs (Louw et al., 2007; Baloyi, 2010). This trend leaves small-scale farmers marginalised and further excluded from profitable niche markets (Mmbengwa, 2009).

\section{Methodology}

The Sarah Baartman District Municipality (formerly Cacadu) consists of nine local municipalities, namely: Baviaans, Blue Crane Route, Camdeboo, Kouga, KouKamma, Ikwezi, Makana, Ndlambe and Sundays River Valley. Sarah Baartman is the largest of the province's six district municipalities, extending over $58243 \mathrm{~km}^{2}$ (Industrial Development Corporation (IDC), 2013). The district municipality is characterised by high unemployment levels and poverty. Many people rely on agriculture, gifts, state pensions and labour remittances for household survival (IDC, 2013).

\footnotetext{
${ }^{1}$ Agribusiness firms are identified by Ayinke (2011), Davis and Goldberg (1957), Goldberg (1998), Minot (2012) as those firms carrying out processing, manufacturing and marketing activities to add value to an agricultural commodity.
} 
Creative commons User License: CC BY-NC-ND

Abstracted by: EBSCOhost, Electronic Journals Service (EJS), Google Scholar, Journal Seek, Scientific Commons,

Food and Agricultural Organization (FAO), CABI and Scopus
Journal of Agricultural Extension

Vol. 22 (3) October, 2018

ISSN(e): 24086851; ISSN(Print); 1119944X

http://journal.aesonnigeria.org

http://www.ajol.info/index.php/jae

Email: editorinchief@aesonnigeria.org

The methodology employed in this study was a qualitative research approach. The rationale behind the use of a qualitative methodology is the descriptive nature of this approach. The use of a qualitative approach enabled the researcher to reach an indepth analysis of the challenges inherent in contract farming relationship between ${ }^{2}$ small-scale farmers and ${ }^{3}$ agribusiness firms. In contrast to the quantitative approach which focuses on statistics and figures, qualitative approach focuses on words of the respondents and the themes emerging from their narratives.

A purposive (judgement) sampling was used in this study for choosing the participants. About 47 small-scale vegetable farmers that met the criteria for inclusion in the study and 15 contracting agribusiness firms were purposively selected to provide a holistic view of contract farming.

Two qualitative research techniques were applied to gather primary data namely, focus group discussions and individual in-depth interviews. In the focus discussions groups, 10 selected individuals discussed a range of topics with the conversation moderated by a facilitator. The individual in-depth interviews were unstructured personal interviews where extensive probing was used to get a single respondent to talk freely. The advantages and disadvantages of focus group discussion versus individual interviews have been discussed extensively in literature (Marshall \& Rossman, 2010). The combination of the two methods allowed to gain substantive insights into the effectiveness of contract farming in commercialisation of small-scale vegetable farmers. The focus group discussions were applied to small-scale vegetable farmers while in-depth interviews were applied to agribusiness firms.

The focus group participants were all African and the majority were Xhosa. Mostly live in the Amathole district municipality (40 of 70). The others stay in different areas of Sarah Baartman district municipality. All the focus group discussion took place in IsiXhosa, the language spoken by the participants. Most interviewees answered in IsiXhosa while some intermittently switched to English. All sessions were audio taped and translated and transcribed into English. To ensure that no information was withheld by the farmers during focus group discussions, thereby remaining hidden and unknown, individual meetings with the farmers were subsequently held in their farming areas to obtain any additional information that may not have emerged during focus group discussions. Although there were seven focus groups, data saturation was reached after the $6^{\text {th }}$ group. Therefore, the researcher used point-of-data saturation in deciding the final number of focus groups needed to collect sufficient data - the point at which no new information or themes relevant to the study emerge from each subsequent interview. The central topic for small-scale farmers' discussion was to gain invaluable insight and a deep engagement on the conditions required by agribusiness firms to engage small-scale vegetable farmers in contractual

\footnotetext{
2 Small-scale farmers: must be involved in primary production with a farm size between 3 (ha) to 12 (ha) as per definition by Agri-bank; must be producing to sell and not for household consumption.

${ }^{3}$ Agribusiness firms: must be leading chains in South Africa; must be involved in processing, value adding and marketing and sales of agricultural commodities; must have been operating for more than five years.
} 
Creative commons User License: CC BY-NC-ND

Abstracted by: EBSCOhost, Electronic Journals Service (EJS), Google Scholar, Journal Seek, Scientific Commons,

Food and Agricultural Organization (FAO), CABI and Scopus
Journal of Agricultural Extension

Vol. 22 (3) October, 2018

ISSN(e): 24086851; ISSN(Print); 1119944X

http://journal.aesonnigeria.org

http://www.aiol.info/index.phpliae

Email: editorinchief@aesonnigeria.org

arrangements and also sought to clarify the agribusiness challenges to effectiveness of contract farming in commercialisation of small-scale farmers.

The in-depth interviews for the agribusiness firms covered the agribusiness firms' characteristics, the contracted commodities, procurement systems, information pertaining to selection criteria followed in selecting farmers to contract with, support services and incentives required and the key challenges that inhibit agribusinesses from engaging in formal legal contractual agreements with small-scale farmers. The questions asked were formulated based on a comprehensive literature review on global commodity chains and allowed for gaining an in-depth understanding of each of the respondents' insights while maintaining a structure that cover the same central themes. All the interviews were with individuals and conducted at their places of work. During the meetings, all the information provided by the interviewees was recorded and notes written down. A second appointment was made with all the respondents for feedback and all the respondents attended the feedback meetings. The collected data during the first interviews were read to the respondents to correct any information that had been previously given. Unclear points were discussed to obtain clearer information.

If qualitative research is to bring meaningful and useful results, it is imperative that the material under scrutiny is analysed in a methodical manner (Pope, Zeibland \& May 2000). Responses from the interviews were analysed to identify general patterns from which recurrent themes were extracted. The imperativeness of data was indicated by the number of times it occurred during the interviews and focus group discussions. A software ATLAS.ti was used. A computer-assisted analysis procedure NCT (Noticing things, collecting things and thinking about things) as described by Friese (2014) was carried out. Friese (2014) argues that noticing things refers to the process of finding interesting things in the data collected when one is reading through transcripts, field notes, documents and reports. Collecting things refers to the process of naming themes that emerge and grouping those that belong together or have the same name. Thinking about things refers to the ability to consider the things that emerged and collected in order to find patterns and relationships in the data (Zhang \& Wildemith, 2005; Friese, 2014). The study then employed open coding with an inductive framework approach. Codes relevant to the research question were created, themes were then established and the data were systematically examined to see ways in which themes were portrayed. The analysis continued until no new information was emerging. Inductive coding allows topics to emerge from the data by conceptualising data and breaking it down into discrete units and organising into categories or codes named to represent the specific phenomenon (Strauss \& Corbin, 1990). According to Marshall and Rossman (2010) through this process themes emerge from the data leading to the development of theories.

\section{Results and Discussions}

The farmer participants varied by gender, age and years of experience. The farmers operated farms with a high diversity of crops and integrated different production systems into their farm operations. The primary products produced included annual 
Creative commons User License: CC BY-NC-ND

Abstracted by: EBSCOhost, Electronic Journals Service (EJS), Google Scholar, Journal Seek, Scientific Commons,

Food and Agricultural Organization (FAO), CABI and Scopus
Journal of Agricultural Extension

Vol. 22 (3) October, 2018

ISSN(e): 24086851; ISSN(Print); 1119944X

http://journal.aesonnigeria.org

http://www.aiol.info/index.phpliae

Email: editorinchief@aesonnigeria.org

vegetables, beans and grains. The experience levels varied widely from farmers with no prior experience to farmers that were born and raised on farms farming. The majority of the farmers operated their farms for more than 21 years. The number of hectares farmed varied from 5 hectares to 20 hectares. All the farmers in the study were pursuing farming as more than a way of making a living. The description of the farmers' success vision during the focus group discussion and interviews clearly reflected the various objectives the farmers have. Three specific themes emerged out of the analyses of the data, these themes are: Bottlenecks in agribusiness chain participation, production inputs and practises in agri-food value chains and trustworthiness of producers and contractors.

\section{Bottlenecks in Agribusiness Value Chain Participation}

Most farmers indicated that they do sell their produce to formal markets. However, they have no written, formal contractual agreements. They have attempted to obtain written contractual agreements with agribusinesses with the assistance of government officials from the Department of Agriculture, Forestry and Fisheries. However, a verbal, informal agreement was the only agreement the agribusinesses were willing to agree to.

The respondents indicated that agribusinesses choose verbal informal contracts as opposed to written formal contracts not because the farmers do not have the ability to produce good-quality commodities and remain competitive within the agribusinesses supply chains, but because agribusinesses will have the responsibility of paying the producers in terms of the contract even if the market is not performing well. To avoid such commitments and market risks, the agribusinesses choose non-binding contracts so that, in the case of over-supply, the agribusiness can decide not to accept the commodity.

Further results on the conditions stipulated by agribusinesses revealed that diseasefree commodities are mostly preferred by the agribusinesses. A group of respondents recounted their informal engagement to supply tomatoes to one of the leading agribusinesses in the province. The farmers had no written agreement. Some of the requirements they had to meet were freshness of produce, size and colour, hygiene, good packaging and barcoding of their produce for easy traceability. This was a challenge for the farmers because they had no washing machine to wash the produce and the packaging boxes were expensive to buy. The farmers mentioned that, to buy production inputs for the following season, they depended on income obtained from the harvested produce. The lack of proper infrastructure resulted in the agribusinesses rejecting their produce and incurring expenses to have their produce washed and packaged by a contractor. It became clear during the focus group discussions that, even if farmers had access to suitable land, they often could not engage in contract farming programmes because of lack of infrastructure, distance of farms to markets and insufficient funds to pay for transportation.

When asked about the challenges the farmers face when interacting with agribusiness firms, the majority of the respondents indicated that some agribusiness firms 
Creative commons User License: CC BY-NC-ND

Abstracted by: EBSCOhost, Electronic Journals Service (EJS), Google Scholar, Journal Seek, Scientific Commons,

Food and Agricultural Organization (FAO), CABI and Scopus
Journal of Agricultural Extension

Vol. 22 (3) October, 2018

ISSN(e): 24086851; ISSN(Print); 1119944X

http://journal.aesonnigeria.org

http://www.ajol.info/index.php/iae

Email: editorinchief@aesonnigeria.org

manipulate quality testing of their produce in order to offer prices below market level. One of the interviewed respondents recounted the following experience:

"A group of small-scale farmers come to the agribusiness seeking an agreement to supply pumpkins to the firm. The farmers receive support services and production inputs from one of the governments departments. The produce procured was of a good quality and sufficient quantity and met the high standards of the formal markets. However, the cultivar grown by the farmers was not a marketable cultivar and not in demand in formal markets. The pumpkins could therefore not be purchased although they met the standards of the agribusiness markets. The respondents indicated that this is the norm with small-scale vegetable farmers: who produce cultivars that are not marketable or in demand in formal agricultural markets".

Most small-scale farmers do not demand high prices for their produce, but their produce is downgraded because they are small-scale farmers and are assumed not to be aware of the procedures that are followed when grading and pricing agricultural produce. According to the respondents, offers made by agribusiness firms for their produce are so low that the farmer makes a loss. Some respondents felt aggrieved that their rejected produce is generally not returned to them by the agribusiness firms when it is rejected. They are required to fetch it at own cost from the agribusiness firms' premises or distribution centres. When the produce is returned to the farmers, it is sometimes not their produce. This leads to distrust between the farmers and the agribusiness firms.

The respondents indicated that they have difficulty in obtaining good-quality seeds and new hybrid cultivars. They indicated that some seeds they obtain from co-ops are mixed seeds from mixed cultivars - sometimes resulting in low production and poorquality produce. The seeds that the small-scale farmers can afford are often from older varieties. To obtain improved hybrid seeds, the respondents often have to travel far and the varieties are usually more expensive and are sold in large quantities.

Smalley (2013) also asserts that, the contractor usually only wants to buy high quality products. However, in farming there will always be second grade. Instead of returning the second grade to the small-scale farmer and make him or her sell and spoil the local market, a better option is often to accept it with a differential price and sell it outside, e.g. selling damaged fruits to a juice maker in the city. A low local market price for second grade is a powerful disincentive for farmers to grow the specific crop.

\section{Production Inputs and Practises in Agri-Food Value Chains}

The respondents indicated that, owing to lack of training and because small-scale farmers are risk-averse, they usually follow inappropriate agricultural practices in their production. Lack of good agricultural practices was stated as one of the factors that deter agribusiness firms from obtaining their commodities from small-scale vegetable farmers. The Agricultural Products Standards Act (Act No. 119) of 1990 provides control over the sale of agricultural products, ensuring that all agricultural products procured comply with the minimum quality standards outlined and specified in the Act. 
Creative commons User License: CC BY-NC-ND

Abstracted by: EBSCOhost, Electronic Journals Service (EJS), Google Scholar, Journal Seek, Scientific Commons,

Food and Agricultural Organization (FAO), CABI and Scopus
Journal of Agricultural Extension

Vol. 22 (3) October, 2018

ISSN(e): 24086851; ISSN(Print); 1119944X

http://journal.aesonnigeria.org

http://www.aiol.info/index.phpliae

Email: editorinchief@aesonnigeria.org

With the exception of only two agribusinesses, the remainder had strict food safety and quality control criteria compulsory for all contract farmers to comply with. The agribusinesses required contract farmers to have a good safety certification audit. The respondents agreed that small-scale farmers struggle to comply with these standards.

With regard to disease control, the interviewed respondents revealed that small-scale vegetable producers use domestic pesticides and herbicides owing to their low costs as compared to expensive commercial pesticides and herbicides. These products are not accepted or recognised by the Agricultural Products Standards Act. The use of domestic pesticides by the producers leaves more residuals on their produce, making it problematic for the product to meet the pesticides and herbicides residue requirements set by the firms and government in response to the demand of consumers and export markets. This leads to the commodity being rejected by highvalue markets because of difficulties in marketing the affected produce.

For small-scale farmers to meet the required quality criteria, it is often necessary to get training. They need to learn and understand the quality selection process. Many companies collaborate with NGOs or government extension workers to train farmers. However, certain crops need specific technical know-how that is not easily available, initially, it can only be provided by the investor (Smalley, 2013).

\section{Trustworthiness of Producers and Contractors}

The interaction of agribusiness firms with their contracted producers involves a very strong trust component. When choosing primary producers to contract with, the interviewed respondents divulged that trustworthiness of producers to deliver a consistent quality and quantity of produce to the agribusiness firms on time is crucial. The agribusiness firms identified that delivery and quality of small-scale producers are inconsistent, and quality and quantity of produce is not guaranteed. These shortcomings stem from a lack of planning by the farmers. Respondents pointed out that available land is usually occupied by large families in the case of small-scale farmers. After the land is shared among the family members, each one is left with a small portion of land to farm on. This results in low quantities of commodities being produced. It is difficult for someone to farm on one to two hectares of land and produce large quantities of commodities, particularly if that person is faced with limited production inputs, insufficient farm equipment and limited credit. In addition to this, the majority of small-scale farmers fail to plan their production cycles to ensure that they will have sufficient commodities available to meet the orders of the agribusiness firms in terms of quality and quantity. Furthermore, increasing transport costs make it difficult to collect small volumes of commodities that are produced by small-scale farmers.

The respondents revealed that many small-scale farmers are not aware of the procedures followed to price their commodity and, as a result, they expect agribusiness firms to pay them a little more than they would obtain from informal markets, regardless of the quality of their produce. In many instances, small-scale farmers want the same price that the agribusiness firm is receiving for the produce. They do not understand that packaging and distribution costs are incurred before the 
Creative commons User License: CC BY-NC-ND

Abstracted by: EBSCOhost, Electronic Journals Service (EJS), Google Scholar, Journal Seek, Scientific Commons,

Food and Agricultural Organization (FAO), CABI and Scopus
Journal of Agricultural Extension

Vol. 22 (3) October, 2018

ISSN(e): 24086851; ISSN(Print); 1119944X

http://journal.aesonnigeria.org

http://www.aiol.info/index.phpliae

Email: editorinchief@aesonnigeria.org

commodity is sold to consumers. According to respondents, the lack of knowledge of pricing leaves small-scale farmers excluded from the agribusinesses supply chains because of their demand for high prices for their commodities. The problem is compounded by the generally low educational levels of small-scale farmers.

The best way to ensure trustworthiness is through goodwill, which is the lubricant for overcoming hurdles in the contract arrangement (Ton \& Van der Mheen, 2013). Unforeseen problems will always appear however, getting it right from the start can reduce a lot of troubles. Generally, smallholders do not count on long term benefits of a chain partnership, but are very responsive to concrete benefits in the short term. Goodwill enhancing activities do not have to be very difficult or expensive. Examples are: provision of educational grants or transport facilities to small-scale farmers; emergency funds for health or funeral costs; etc. As production risks are usually quite high, the facilitation of crop diversification next to the contract target crop is a good strategy to build goodwill and to support food security. For example, offering smallscale farmers access to cash, harvest storage or processing services for other crops that are not under the contract (Ton \& Van der Mheen, 2013).

\section{Conclusion and Recommendations}

The factors that influence the contract farming partnership between agribusiness firms and small-scale farmers are both internal and external. The internal factors include the compliance of small-scale farmers with contractual agreements, reliability of services offered by small-scale farmers to agribusiness firms and the consistency of produce quantity and quality. The external factors include the availability of infrastructure and farm implements, as well as access to land. Furthermore, the results make it clear that contract farming fails as a development strategy to link small-scale farmers to lucrative agricultural markets. Small-scale farmers find it difficult to engage in contract farming arrangements with agribusiness firms owing to a number of unique challenges they face. There seems to be little merit in the adoption of contract farming as a development strategy for improving the basic livelihoods of the rural poor. Unless there are interventions and the conditions and incentives related to agribusiness are met, the divide will widen between small-scale producers and large agribusiness firms, with agribusiness firms opting to do business with a network that satisfies their requirements, while small-scale producers continue to be marginalised and entrapped in the cycle of poverty. The study confirms that the successful participation of small-scale producers in lucrative markets cannot be guaranteed if broader socio-economic conditions, such as investing in human and social capital, are not addressed. The findings in the study serve as indicators to guide the key role-players in the agricultural sector in strategically addressing the factors constraining small scale farmers so as to increase the farmers' competitiveness in high value markets.

\section{Acknowledgements}

This research was supported by the National Institute for the Humanities and Social Science. 
Creative commons User License: CC BY-NC-ND

Abstracted by: EBSCOhost, Electronic Journals Service (EJS),

Google Scholar, Journal Seek, Scientific Commons,

Food and Agricultural Organization (FAO), CABI and Scopus
Journal of Agricultural Extension

Vol. 22 (3) October, 2018

ISSN(e): 24086851; ISSN(Print); 1119944X

http://journal.aesonnigeria.org

http://www.aiol.info/index.phpliae

Email: editorinchief@aesonnigeria.org

\section{References}

Ayinke, O. O. (2011). Contract farming in developing emerging farmers in South Africa: Exploring the Gledhow Mansomini sugarcane scheme. Master's dissertation, Stellenbosch University, South Africa. Retrieved from http://citeseerx.ist.psu.edu/viewdoc/download?doi=10.1.1.922.8478\&rep=rep1 \&type $=$ pdf

Baloyi, J. K. (2010). An analysis of constraints facing smallholder farmers in the agribusiness value chain: a case study of farmers in the Limpopo Province. Master's dissertation, University of Pretoria, South Africa.

Retrieved from www.scirp.org/(S(czeh2tfqyw2orz553k1w0r45))/reference/ReferencesPapers.a spx?ReferencelD=1617761

Berdegué, J. A., Biénabe, E., \& Peppelenbos, L. (2008). Keys to Inclusion of smallscale producers in dynamic markets - Innovative practice in connecting smallscale producers with dynamic markets. Regoverning Markets Innovative Practice Series. London: International Institute for Environment and Development (IIED).

Department of Agriculture, Forestry and Fisheries (DAFF). (2010a). Budget speech. Pretoria: Department of Agriculture, Forestry and Fisheries.

Davis, J., \& Goldberg, R. (1957). The genesis and evolution of agribusiness. In Davis, J. and Goldberg, R. (Eds.), A Concept of Agribusiness (pp.4-6). Harvard University.

Fischer, E., \& Qaim, M. (2012). Linking smallholders to markets: determinants and impacts of farmer collective action in Kenya. World Development, 40(6): 12551268.

Friese, S. (2014). Qualitative data analysis with ATLAS. ti (2 $2^{\text {nd }}$ ed.) Sage Publications.

Goldberg, R. A. (1998). Why the International Agribusiness Management. Global Agribusiness for the future. Boston: IAMA

Greenberg, S., \& Paradza, G. (2013). Smallholders and the Walmart effect in South Africa. In Greenberg, S. (Ed.), Smallholders and agro-food value chains in South Africa: Emerging practices, emerging challenges. Bellville: Institute for Poverty, Land and Agrarian Studies (PLAAS).

Ha, T. M., Bosch, O. J., \& Nguyen, N. C. (2015). Systemic interventions addressing market access challenges of smallholder vegetable farmers in Northern Vietnam. International Journal of Markets and Business Systems, 1(2):136158.

Industrial Development Corporation (IDC). (2015). Small Town Regeneration in Amathole: Aspire- Economic Development Agency in Amathole, EC. Retrieved from https://www.idc.co.za/home/ads-home/more-ads-projects/402-aspiredevelopment-agency.html

Johanson, R. K., \& Saint, W. (2007). Cultivating knowledge and skills to grow African agriculture: A synthesis of institutional, regional and international review. Washington DC: World Bank. Retrieved from http://documents.worldbank.org/curated/en/629031468340199694/Cultivating- 
Creative commons User License: CC BY-NC-ND

Abstracted by: EBSCOhost, Electronic Journals Service (EJS), Google Scholar, Journal Seek, Scientific Commons,

Food and Agricultural Organization (FAO), CABI and Scopus
Journal of Agricultural Extension

Vol. 22 (3) October, 2018

ISSN(e): 24086851; ISSN(Print); 1119944X

http://journal.aesonnigeria.org

http://www.ajol.info/index.php/iae

Email: editorinchief@aesonnigeria.org

knowledge-and-skills-to-grow-African-agriculture-a-synthesis-of-an-institutionalregional-and-international-review

Jordaan, H. (2012). New Institutional Economics analysis of emerging irrigation farmers' food value chains. PhD thesis, University of the Free State, Bloemfonein, South Africa. Retrieved from https://scholar.google.com/citations?user=DEJIhKUAAAAJ\&hl=en\&newwindow $=1 \& \mathrm{oi}=\mathrm{sra}$

Koranteng, K. Y. (2010). Contract farming model of financing smallholder farmers in South Africa: The case of the IDC-Kat River citrus development scheme. Master's dissertation, Stellenbosch University, South Africa. Retrieved from https://oatd.org/oatd/record?record=handle\%5C\%3A10019.1\%5C\%2F8579

Little, P. D., \& Watts, M. J. (Eds). (1994). Living under contract: Contract farming and agrarian transformation in sub-Saharan Africa. Madison: University of Wisconsin Press.

Louw, A., Jordaan, D., Ndanga, L., \& Kirsten, J. F. (2008). Alternative marketing options for small-scale farmers in the wake of agri-food supply chains in South Africa. Agrekon, 47(3): 287-308.

Louw, A., Vermeulen, H., Kirsten, J., \& Madevu, H. (2007). Securing small farmer participation in supermarket supply chains in South Africa. Development Southern Africa, 24(4):539-551.

Marshall, C., \& Rossman, G. B. (2010). Designing qualitative research. Thousand Oaks, California: Sage.

Minot, N. (2012). Food price volatility in Africa: Has it really increased? IFPRI Discussion Paper 01239. Retrieved from http://dx.doi.org/10.2139/ssrn.2197406

Mmbengwa, V. M., Groenewald, J. A., Van Schalkwyk, H. D., \& Maiwashe, A. (2012). Analysis of capacity building indicators and their influences on the viability of farming small, micro and medium enterprises (SMMEs) in South Africa. African Journal of Business Management, 6(36):9923-9935.

Ortmann, G. F., \& King, R. P. (2010). Research on agri-food supply chains in Southern Africa involving small-scale farmers: Current status and future possibilities. Agrekon, 49(4):397-417.

Oya, C. (2012). Contract farming in Sub-Saharan Africa: A survey of approaches, debates and issues. Journal of Agrarian Change, 12(1):1-33.

Pope, C., Ziebland, S., \& Mays, N. (2000). Qualitative research in health care: analysing qualitative data. BMJ: British Medical Journal, 320: 114.

Randela, R., Alemu, Z. G. \& Groenewald, J. A. (2010). Factors enhancing market participation by small-scale cotton farmers. Agrekon, 47(4):451-469.

Sikwela, M. M., \& Mushunje, A. (2013). The impact of farmer support programmes on household income and sustainability in smallholder production: A case study of the Eastern Cape and KwaZulu-Natal farmers, South Africa. African Journal of Agricultural Research, 8(21): 2502-2511.

Smalley, R. (2013). Plantations, Contract Farming and Commercial Farming Areas in Africa: A Comparative Review. Retrieved from https://www.plaas.org.za/sites/default/files/publicationspdf/FAC_Working_Paper_055.pdf 
Creative commons User License: CC BY-NC-ND

Abstracted by: EBSCOhost, Electronic Journals Service (EJS),

Google Scholar, Journal Seek, Scientific Commons,

Food and Agricultural Organization (FAO), CABI and Scopus
Journal of Agricultural Extension

Vol. 22 (3) October, 2018

ISSN(e): 24086851; ISSN(Print); 1119944X

http://journal.aesonnigeria.org

http://www.ajol.info/index.php/iae

Email: editorinchief@aesonnigeria.org

Strauss, A., \& Corbin, J. (1990). Basics of qualitative research: Grounded theory, procedures and techniques. Thousand Oaks, CA, US: Sage Publications, Inc.

Ton, G., \& Van der Mheen, J. (2013). Contract Farming: tool for reflection on critical issues in contract farming arrangements in developing countries. Retrieved from

https://english.rvo.nl/sites/default/files/2013/11/Contract\%20Farming\%20Check list.pdf

Van Schalkwyk, H. D, Groenewald, J. A, Fraser, G. C. G., Obi, A., \& Van Tilburg, A. (2012). Unlocking markets to smallholders: Lessons from South Africa. The Netherlands: Mansholt Publication series.

Zhang, Y., \& Wildemuth, B. M. (2005). Qualitative analysis of content. Applications of social research methods to questions in information and library science, 1 (2):1-12. 